Palestine Exploration Quarterly

\title{
Mar Tukla
}

\section{Leslie W. Troughton}

To cite this article: Leslie W. Troughton (1890) Mar Tukla, Palestine Exploration Quarterly, 22:3, 186-186, DOI: 10.1179/peq.1890.22.3.186

To link to this article: http://dx.doi.org/10.1179/peq.1890.22.3.186

曲 Published online: 20 Nov 2013.

Submit your article to this journal $\pi$

Џlll Article views: 3

Q View related articles $₫$ 


\section{THE MALULA DIALECT.}

The interesting paper in last Quarterly Statement by Dr. Bliss on the Syriac Dialect of Malula gives several indications of the archaic character of the ordinary Fellah dialect of Palestine to which I have lately again called attention.

As regards the phonology-

ك, prowounced ch (as in "chaff"), is the common Fellah pronunciation of the letter.

* pronounced without guttural sound is also not unconmon among Fellahîn.

$\varepsilon$ for hamza, is also a Fellah change ("Lanberg," p. 82, gives many examples).

بش pronounced $\omega$, as in sejratha, "tree," is the Fellah sejerah for shejerah, "tree."

In grammatical forms-

$o$ for 3rd person singular possessive is the Fellah g. Abu, " his father," for literary $A b-h u$.

Phash answers to the common Fellah Fihâsh.

Some of the words are also so used in Fellah speech, e.g., Shenna, "rock" (as in Hebrew); Ho, or Hey, "this"; Blato (Fellah, Bladd), "country"; Blota (Fellah, Belled), "village."

The Fellah dialect, indeed, seems to have been but little affected by the literary Arabic, and retains much of its old Aramaic character.

C. R. C.

\section{MAR TUKLA.}

In the paper on "Ma'lula and its Dialect," by Mr. Bliss, he says, "Mar Tukla is said to have been a companion of St. Paul's, the tradition is doubtless ancient." (Quarterly Statement, April, 1890, page 83.) This would, I think, hardly lead one to understand that the story of St. Paul and Thecla, as related in the apocryphal "Acts of Paul and Thecla" (to which I imagine Mr. Bliss refers) was as old as 170 or 180 A.D., which is the date Dr. Salmon assigns to it.

Leslie W. Troughton. 